\title{
ESTRATÉGIA EM FOCO
}

\author{
Por Marco Aurélio Rodrigues \\ Professor do CEPEAD/CAD/UFMG. \\ E-mail: marco@face.ufmg.br
}

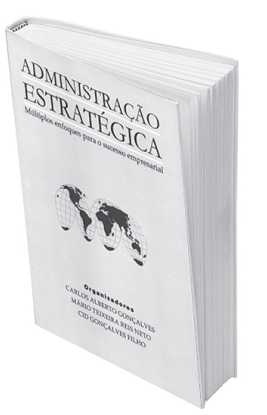

\section{ADMINISTRAÇÃO ESTRATÉGICA - MÚLTIPLOS ENFOQUES PARA 0 SUCESSO EMPRESARIAL}

De: Carlos Alberto Gonçalves, Mário Teixeira Reis Neto e

Cid Gonçalves Filho (Organizadores).

Belo Horizonte: CEPEAD/UFMG, 2001. 317 p.
Entendida como uma forma de pensar o futuro, uma maneira de conferir unidade e direção às ações empresariais, ou ainda, como um mecanismo para promover mudanças, o campo da administração estratégica oferece aos interessados um número elevado não apenas de ingredientes como também de possibilidades para combiná-los. Um exame mesmo breve da literatura nessa área revela ao observador uma prodigalidade de perspectivas e abordagens e, caso não se disponha previamente de um quadro de referência ou uma "carta de navegação", não é difícil se perder no emaranhado de pontos de vista que o campo oferece. É o que mostra, por exemplo, Safári de Estratégia, uma penetrante revisão do campo realizada por Mintzberg, Ahlstrand e Lampel, em que, juntamente com a complexidade das questões que cer- cam o tema, são explicitadas algumas das formas alternativas de se pensar a estratégia.

É, portanto, nessa moldura e com a intenção original de oferecer ao leitor "orientações para a construção mais elaborada do pensamento estratégico" que se incorpora ao amplo estoque da literatura existente o livro Administração estratégica - múltiplos enfoques para o sucesso empresarial.

Obra coletiva, o trabalho é resultado da iniciativa de professores e alunos do Centro de Pós-Graduação e Pesquisas em Administração (CEPEAD) da UFMG. Estruturado em seis partes e contendo 15 artigos, produto da colaboração de 18 participantes, o livro adota, predominantemente, o enfoque do posicionamento de Michael Porter, corrente preponderante, até recentemente, como a mainstream desse campo de estudos e de prática profissional.

Na primeira parte - "Introdução à estratégia" - composta por dois artigos, os autores procuram, respectivamente, fixar uma abordagem ampliada para referenciar o campo e discutir, na perspectiva da teoria das organizações e na ótica instigante da análise do discurso de inspiração foucaultiana, a problemática da "produção do saber" na área.

A segunda parte - "A estratégia, a organização e a cultura" - compõe-se de quatro artigos. O primeiro deles traz uma proposta interessante, na qual os autores buscam discernir o "tratamento dispensado (ou não dispensado) ao conceito de estratégia" ao longo do desenvolvimento da teoria organizacional em cada uma de suas "escolas de pensamento". No segundo artigo, os autores objetivam 
"sugerir estratégias que não podem ser facilmente copiadas e que aumentam tanto o valor como a expectativa de vida da empresa" elaborando seus argumentos em torno do conceito de "estratégias invisíveis" ou, como preferem denominar, "estratégias obscuras". Dentre as conclusões apresentadas vale ressaltar a afirmação, no mínimo contundente, de que a "vantagem competitiva reside nos níveis estratégico e gerencial das organizações, sendo o nível operacional apenas uma ferramenta de apoio para suas características estratégicas, culturais e gerenciais". O terceiro artigo dessa parte introduz a cultura corporativa nas discussões sobre o tema e, a partir de observações empíricas, o autor tenta mostrar como a cultura "exerce um papel de filtragem" na eleição daqueles aspectos do ambiente empresarial que são "julgados importantes e merecedores de atenção". Encerra essa parte um artigo cuja proposta é oferecer ao leitor um inventário dos principais modelos e processos de mudança nas organizações.

Um único artigo compõe a terceira parte do trabalho - "A estratégia e o conhecimento". Indagando-se quanto à pertinência de uma "gestão do conhecimento" o autor tece, à luz das contribuições de inúmeros analistas e estudiosos do tema, considerações sobre aspectos variados envolvendo o conhecimento.

"Estratégias genéricas, de marketing e de logística" é o título da quarta parte do livro, que antecipa o conteúdo dos textos ali contidos. No primeiro artigo, são revistos os conceitos porterianos de vantagens competitivas e estratégias genéricas, enquanto que o segundo artigo é direto nas suas intenções de explicitar os principais enfoques das estratégias empresariais na ótica do marketing. Para o autor, uma vez que é o mercado a matriz original que "norteia as ações da empresa", o marketing é seu interprete primordial. O artigo "Estratégia corporativa: da perspectiva neoclássica à supply chain management", apresenta argumentos e caminhos promissores para se pensar a questão da estratégia em bases renovadas, com destaque para a elaboração de contribuições teóricas seminais originárias no campo da economia.

A parte cinco da coletânea - "A estratégia em mercados globalizados" - discute o conceito de globalização, seus desdobramentos e a formação das empresas globais relacionando esses temas à concepção e implementação de estratégias em "cenários de hipercompetitividade". O artigo dessa parte trabalha a questão, ressaltando a elaboração da visão e sua importância para o sucesso empresarial em um contexto globalizado.

A sexta e última parte - "Modelos aplicados: ferramentas e estudos de casos" - apresenta três artigos e compõe o que pode ser considerado como o núcleo empírico do livro. No primeiro deles os autores ressaltam que a diversidade de abordagens ou escolas de pensamento dentro do campo, ao oferecer "visões parciais do todo", tende a se constituir em um obstáculo efetivo à incorporação do conceito de estratégia ao ambiente empresarial. Partindo da premissa que a efetividade de uma organização requer necessariamente compatibilidade e coerência entre sua visão de futuro e os fatores internos e externos - o que é definido como postura estratégica da empresa - a intenção dos autores é, precisamente, esboçar os contornos de uma ferramenta para avaliar, junto à alta gerência, essa postura. No segundo artigo são evidenciados os resultados de uma pesquisa exploratória no setor têxtil mineiro, com o objetivo de levantar "os principais fatores internos e as principais variáveis externas que afetam o gerencia- mento e a administração estratégica" do setor. A partir dos resultados obtidos, os autores propõem a replicação da pesquisa em outros setores da economia. O terceiro e último artigo desta parte e da coletânea examina como a privatização e reestruturação afetaram o desempenho e a competitividade de duas empresas do setor siderúrgico. Dentre as conclusões do estudo, o autor revela que a "influência da privatização é raramente direta", não restringindo "os gerentes em suas escolhas na implementação de estratégias". Além disso, observa o autor que as informações obtidas "suportam o ponto de vista de que a atitude gerencial, mais do que a privatização, é a influência chave sobre as decisões a serem tomadas e a performance de longo prazo de uma empresa".

É inegável que o livro contempla múltiplas abordagens, mas elas estão circunscritas, em sua grande maioria, ao ponto de vista da corrente do posicionamento de Michael Porter. Se por um lado, essa orientação tem o mérito de ressaltar para o leitor os limites do planejamento clássico como forma de pensar a administração estratégica, por outro lado, ao não contemplar perspectivas que adotam suposições teóricas distintas quanto à empresa, ao processo e os resultados da estratégia, a própria obra perde a possibilidade de dialogar com outras abordagens e linhas de pensamento, uma vez que, no ambiente concreto em que se move a empresa, nem sempre as alternativas, suposições e riscos se encaixam no figurino clássico. Sem limitar o alcance e o valor das contribuições da obra, merece destaque o esforço de aglutinar pessoas de um mesmo centro de ensino e pesquisa, na reflexão coletiva em torno de um tema complexo e vital ao universo organizacional e às práticas de gestão no Brasil. 